\title{
Keloids: Current Therapies in Barbados
}

\author{
OJ Nelson ${ }^{1}, \mathrm{~J} \mathrm{Ward}^{2}$, AL Forde ${ }^{3}, \mathrm{~N}_{\text {Ojeh }}{ }^{1}$
}

\begin{abstract}
Keloids are characterized by scar tissue overgrowth on the skin beyond the borders of the original wound following an abnormal wound healing process and tend not to regress. These disfiguring scars can cause pain, itching and inflammation in the patient leading to an emotional and psychological impact and a sub-standard quality of life. A variety of treatments, using surgical and non-surgical approaches, exists that have been reported to be beneficial. However, no one treatment currently stands out as the most optimal due to a number of factors including different keloid subtypes. Often, a combinational approach to its treatment generates the best results. The incidence of keloid and hypertrophic scarring is very high in African, Hispanic and Asian populations and as yet, the multifactorial aetiology of this disorder is still not clear. Very few published studies on keloid scarring among the Caribbean population and, in particular, the Barbadian population has been reported to-date. The aim of this review is to explore and discuss the current literature of the various keloid treatment modalities typically used in Barbados along with keloid management. These treatments include: the intralesional corticosteroid injection and the triamcinolone acetonide, imiquimod, excision, pressure dressing, cryotherapy, silicone gel sheeting and radiation. Regarding keloid management, a wellplanned treatment strategy tailored to suit the individual patient's needs by an experienced healthcare physician is key in achieving the best outcome with improved cosmesis. The management of the patients'symptoms as well as patients' compliance with post-treatment care, is also an important factor to consider.
\end{abstract}

Keywords: Keloids, recurrence review, treatment, wound healing

\section{Queloides: terapias actuales en Barbados}

\author{
OJ Nelson ${ }^{1}, \mathrm{~J}$ Ward ${ }^{2}$, AL Forde ${ }^{3}, \mathrm{~N}_{\text {Ojeh }}{ }^{1}$
}

\begin{abstract}
RESUMEN
Los queloides se caracterizan por un crecimiento excesivo del tejido de la cicatriz en la piel más allá de los bordes de la herida original, tras un proceso anormal de cicatrización de la herida, sin tendencia a la reversión. Estas cicatrices desfigurantes pueden causar dolor, picazón e inflamación en el paciente, que producen un impacto emocional y psicológico y conducen a una calidad de vida subestándar. Existe una variedad de tratamientos, basados en métodos quirúrgicos y no-quirúrgicos, reportados como beneficiosos. Sin embargo, ningún tratamiento sobresale actualmente como el más óptimo, debido a un número de factores, incluyendo
\end{abstract}

From: ${ }^{1}$ Faculty of Medical Sciences, The University of the West Indies, Cave Hill, St Michael, Barbados, ${ }^{2} 36$ th Avenue Belleville, St Michael, Barbados and ${ }^{3}$ Suite 3 Pine Medical Centre, $3^{\text {rd }}$ Avenue Belleville, St Michael, Barbados.
Correspondence: Dr N Ojeh, Faculty of Medical Sciences, The University of the West Indies, Cave Hill Campus, PO Box 64, Bridgetown BB 11000, St Michael, Barbados, West Indies. Email:nkemcho.ojeh@cavehill.uwi.edu 
diferentes subtipos de queloides. A menudo, un enfoque combinado de su tratamiento genera los mejores resultados. La incidencia de cicatrices queloides e hipertróficas es muy alta en las poblaciones africanas, hispanas y asiáticas, y hasta el momento, la etiología multifactorial de este trastorno aún no está clara. Hasta la fecha, se han reportado muy pocas publicaciones de estudios sobre la cicatrización de queloides entre la población caribeña, y en particular, la población de Barbados. El objetivo de este estudio es explorar y discutir la literatura actual de las varias modalidades de tratamiento del queloide usadas típicamente en Barbados junto con el manejo del queloide. Estos tratamientos incluyen: acetónido de triamcinolona, inyección de corticoesteroide intralesional, imiquimod, escisión, apósito de presión, crioterapia, recubrimiento con gel de silicona, y radiación. En cuanto al manejo de los queloides, una estrategia de tratamiento bien planificada adaptada a las necesidades de cada paciente por un médico experimentado es clave para lograr el mejor resultado con cosmesis óptima. El manejo de los síntomas de los pacientes, así como la conformidad de los pacientes con la atención del posttratamiento, es también un factor importante a considerar.

Palabras clave: Queloides, revisión de la recurrencia, tratamiento, cicatrización de la herida

West Indian Med J 2017; 66 (6): 649

\section{INTRODUCTION}

Wound healing is an organized and complex series of processes, which results in the restoration of tissue structure integrity and functions of the damaged tissue. It is temporally categorized into three overlapping phases namely, inflammation, granulation tissue formation and tissue remodelling (1). Any defects that occur during any of the wound healing phases can give rise to the development of keloids.

Keloid scars are proliferative and largely disfiguring scars that result owing to events such as a cutaneous injury, inflammation, surgery, elective cosmesis, burns, foreign body reactions, or occur spontaneously. They are characterized by their shiny, hard, smooth, often dome-shaped appearances that may develop years after the initial insult and rarely regress. These benign fibrous growths are characterized by scar tissue overgrowth beyond the borders of the original wound and tend to recur after excision (Fig. 1).

The over-proliferation of the dermal fibroblasts, the over-production of collagen fibres and other extracellular matrix or decreased degradation of collagen can lead to keloid or hypertrophic scar formation (2).

\section{Keloid pathophysiology}

The aetiology of keloids is poorly understood. However, the cell and molecular events implicated in keloid pathology are now being elucidated. Fibroblast-specific growth factors such as transforming growth factor-beta (TGF- $\beta$ ), epidermal growth factor (EGF), vascular endothelial growth factor (VEGF), connective tissue growth factor (CTGF) and platelet-derived growth factor [PDGF] $(3,4)$ are among some of the factors that have been implicated in the development of keloids. Studies have also shown that nutrition may be a contributing factor in keloid formation (5).

\section{Genetics and incidence of keloids}

A number of chromosomal loci have been identified that are linked with the risk of developing keloids (6). Moreover, familial aggregation and twin studies have reported various modes of inheritance (7) suggesting a genetic component and predisposition to keloid development. The role of human leukocyte antigen (HLA) subtypes has also been implicated (8). In keeping with

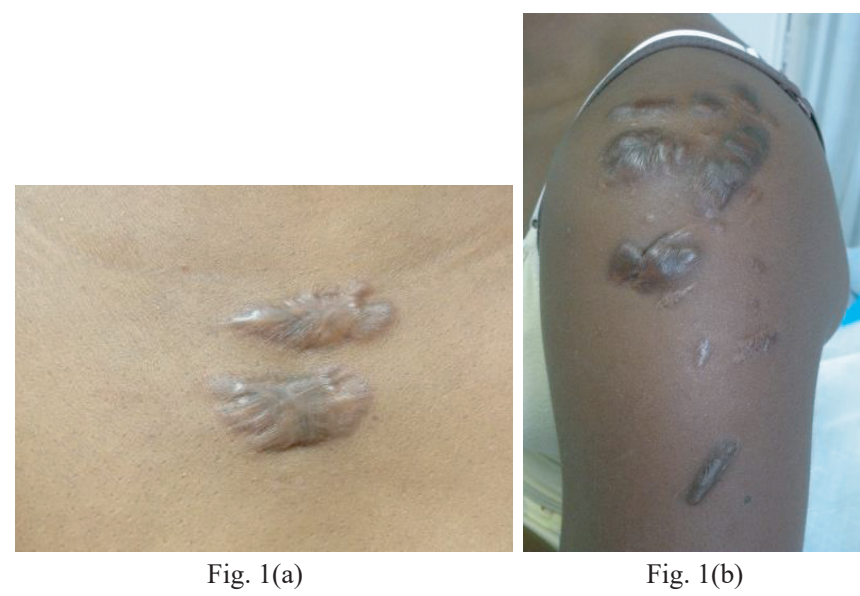

Fig. 1: Chest (A) and Shoulder (B) keloid scars. These scars extend beyond the borders of the original wound and tend not to regress. 
the proposed genetic model of the disease, keloids occur most frequently in persons of 10-30 years of age. There is also an equal risk in both males and females, with females showing a slightly higher incidence. This is likely due to the higher levels of cosmetic procedures undertaken by females, such as ear piercing. They are predominantly reported in persons of darker skin, with studies demonstrating a 15 times higher-risk in this population (9). The incidence of keloid and hypertrophic scarring is high in African, Hispanic and Asian populations and estimated to be $4.5 \%-16 \%$ (10) although, it may occur in any ethnic group particularly after surgery or trauma to the chest or shoulder region.

\section{Anatomical location and histopathology of keloids}

The most common anatomical sites for keloids include: the chest, shoulders, upper arms, cheeks, skin overlying joints, with earlobes being reported with the highest frequency. Of note, the anatomical site of a keloid appears to affect its morphological characteristics. The major source of histopathology in keloids is found in the reticular layer of the dermis. It is composed of dense connective tissue including collagen and fibroblasts. The damage to this layer leads to the deposition of thick hyalinised collagen. Furthermore, recent research has provided three distinct findings only present in keloid specimens namely: (a) the presence of a tongue-like advancing edge underneath normal-appearing epidermis and papillary dermis, (b) horizontal cellular fibrous band in the upper reticular dermis and (c) prominent fascialike band (11).

\section{Studies on keloids in the Caribbean}

To-date, there are very few published studies on keloid and hypertrophic scarring among the Caribbean population and, in particular, the Barbadian population. Bayat and co-workers (12) examined the site-specific morphology of keloid scars in Afro-Caribbean people in Jamaica (12). Bayat et al (13) studied the clinical characteristics of 211 cases of keloid scarring in Afro-Caribbeans in Jamaica (13). Another study investigated the genetic predisposition to keloid formation in the Jamaican population (14). More recently, a study investigated the association of HLA-DRB $1 *$ and keloid disease in an Afro-Caribbean population (15). Ashcroft and co-workers (16) assessed the influence of HLA class I and class II loci on the prevalence of keloid disease in Jamaican Afro-Caribbeans (16). In Barbados, Smith and McGrouther (17) carried out a study on a total of 126 keloids from patients in Barbados and
Manchester to evaluate the natural history and spontaneous resolution of keloid scars to develop prognostic information for the patients and to provide the baseline for future treatment trials (17). Narakula and Shenoy [2008] (18) conducted a prospective clinical study of 46 ear keloids in 31 patients in Barbados using three protocols for keloid treatment including keloid excision and postoperative intralesional triamcinolone injection, keloid excision followed by postoperative superficial X-ray, and keloid excision and a combination of superficial X-ray therapy and intralesional triamcinolone.

\section{The Treatment of keloids in Barbados}

Various forms of treatment exist for keloids including intralesional steroids, topical corticosteroids, silicone gel sheeting, pressure therapy, surgical excision, cryotherapy, laser therapy, radiation, photodynamic therapy, calcineurin inhibitors, immune response modulators, chemotherapy agents: interferon, 5-fluorouracil, mitomycin $\mathrm{C}$ and bleomycin. However, no current single treatment has been shown to completely eradicate keloid scars effectively due to the various factors such as age, ethnicity, gender and anatomical location of the keloid (19). Almost all of the available therapies have significant adverse effects and/ or are painful. Therefore, patients often have to live with their symptoms which include pain and pruritus as well as the emotional and psychological impact of these disfiguring scars. Currently, there are a number of treatment options available for keloids in Barbados. This review will explore and discuss the current literature of these treatment modalities along with keloid management.

\section{Intralesional steroids}

Corticosteroids, and in particular intralesional corticosteroid injections, are considered the first-line of approach for the treatment of keloids. There are a number of mechanisms that are thought to be responsible for reducing scar formation, the central one being the suppressive effect on the inflammatory process (20). Others include: the inhibition of collagen synthesis and fibroblast growth, enhancing collagen degradation, reducing TGF- $\beta 1$ and inducing vasoconstriction causing tissue hypoxia (20).

For the treatment of keloids, several corticosteroids can be used including: hydrocortisone acetate, methyl prednisolone and dexamethasone. However, the most commonly used intralesional corticosteroid is triamcinolone acetonide [10-40 mg/mL] (Fig. 2). 
Three injections are given every three to four weeks for up to six months or more (21). Intralesional corticosteroid therapy has had some success in studies with response rates varying from 50 to $100 \%$, with reported recurrence rates varying from nine to $50 \%(22,23)$. This form of treatment has been reported to be used alone or as part of a combinational therapy with 5-fluorouracil, surgery, pulsedye laser, radiation therapy and cryotherapy $(24,25)$.

A number of issues have arisen concerning the use of intralesional corticosteroids. Pain resulting from injection is common and may be managed by the administration of intralesional lidocaine (26). Others reported are atrophy, telangiectases, ulcerations, and hypopigmentation (27). Darker-skinned patients present with higher occurrence of hypopigmentation and should be advised accordingly. In Barbados, depending on a number of keloid parameters, triamcinolone acetonide injection at a concentration of $40 \mathrm{mg} / \mathrm{mL}$ is the preferred treatment method and is generally used as a monotherapy. However, in the cases of bulbous keloids with significant cosmetic deformity, using a combined approach of surgical excision and triamcinolone acetonide is more efficacious. Close monitoring of the scar site is essential to avoid a recurrence (personal observations). Indeed, the use of triamcinolone acetonide as an adjunct therapy to both surgical excision and combined surgical excision and radiotherapy has been published with positive treatment outcomes in Barbados (18).

\section{Surgical excision}

The surgical excision of keloids is amongst the most practical methods of keloid removal. However, excision results in a new wound where aggressive collagen synthesis can lead to a similar or even larger keloid. It has been found that the likelihood of recurrence is between 50 and $100 \%$ (28); hence, surgical excision is not recommended as a monotherapy. Instead, it should be combined with other treatment modalities such as corticosteroid injection, radiotherapy, interferon injection and pressure therapy. Silicone gel has also been used in

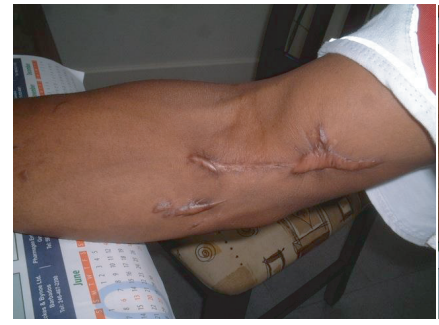

Fig. 2(a)

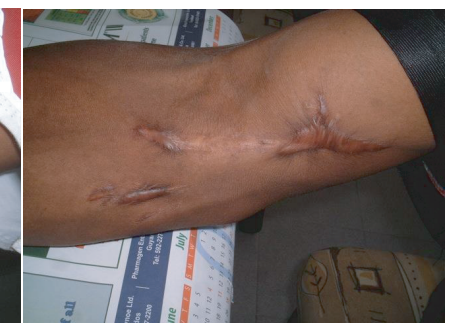

Fig. 2(b)
Fig. 2: Keloids before (A) and one month into treatment with triamcinolone acetonide $40 \mathrm{mg} / \mathrm{mL}$ injections (B) conjunction with keloid excision with varying degrees of success (29). Different methods exist for the surgical removal of keloids as well as flattening and reducing keloid scars and the method employed depends on many factors including: keloid size, location, patient's age and skin type. Some of the surgical methods include: W-plasty, Z-plasty, excision with grafting, linear closure and flap coverage (30). The experience of the operating surgeon and technique used are often directly correlated with the final scar cosmesis (31). In Barbados, the surgical excision of pinna keloids tends to be used as an effective monotherapy without keloid recurrence provided that all the keloid tissues is removed (Fig. 3).

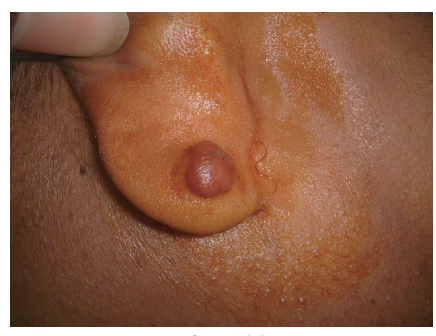

Fig. 3(a)

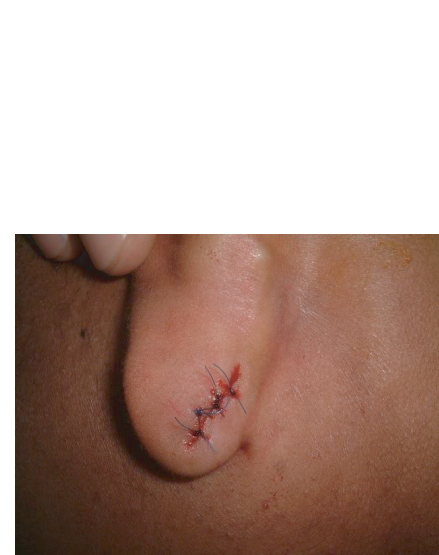

Fig. 3(c)

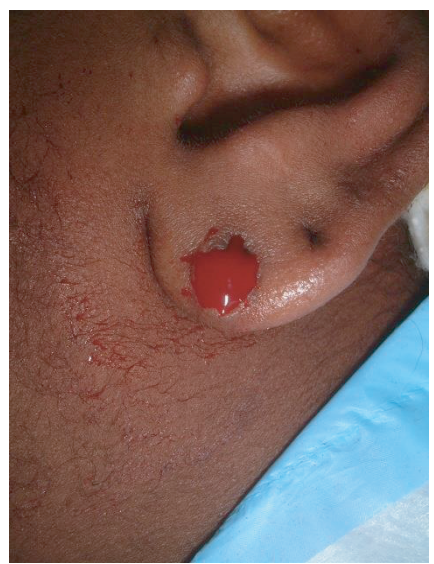

Fig. 3(e)

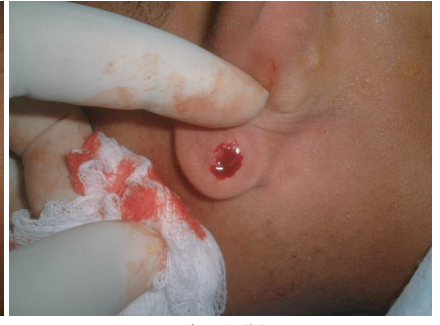

Fig. 3(b)

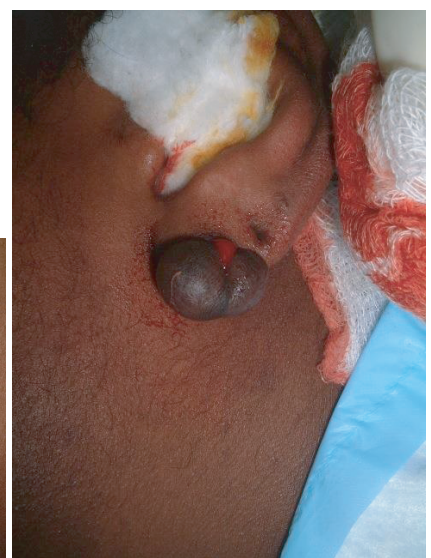

Fig. 3(d)

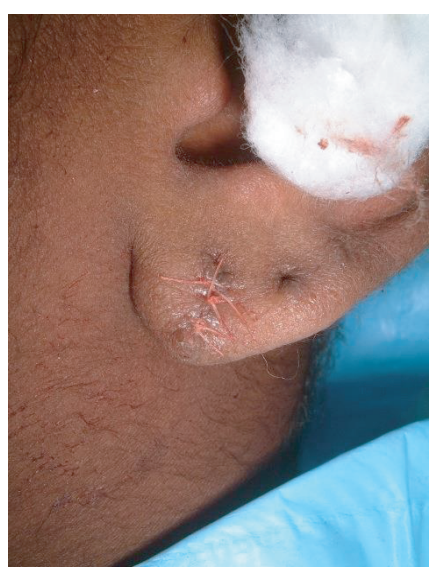

Fig. 3(f)
Fig. 3: Pinna keloid surgical excision used as monotherapy. Pinna keloids before surgical excision (A, D) directly after excison (B, E) and resulting wounds closed with sutures with no tension $(\mathrm{C}, \mathrm{F})$. 
However, close monitoring of the scar site by both the patient and the doctor is important to prevent a recurrence. For all other keloids, surgical excision is often combined with corticosteroid injection, radiotherapy (18), silicone gel / liquid or imiquimod cream (personal observations).

\section{Silicone based products}

Silicone gel sheeting has been employed since the 1980s in the treatment of keloids and hypertrophic scars; it is now considered the first-line of treatment for small keloids and hypertrophic scars (32). The underlying mechanism of this therapy is not entirely understood although a few hypotheses have been proposed. The dominant opinion states that silicone-based products enhance the hydration of the corneum stratum, reduce collagen synthesis and increasing fibroblast regulation (33). It is also thought that silicone-based products increase the temperature and oxygen tension (34). A study reported that $60 \%$ of the patients receiving the treatment experienced the flattening of the keloid. In addition, other beneficial effects such as reduced pain, tenderness and pruritus left $90 \%$ of the patients satisfied with the outcomes of the treatment (35). Studies have shown that best results are attained if the silicone sheeting is worn for 12 to 24 hours a day for two to three months (36). Despite the recorded response rates, there has been some controversy regarding silicone-based products. Recently, a Cochrane review concluded that the studies provided weak evidence in the treatment and prevention of keloid scarring using silicone gel sheeting and that the studies investigating this therapy were of poor quality (29). Of note, although this leaves a question as to the efficacy of silicone-based products, studies are continuing to produce convincing support in favour of their applications $(37,38)$. Various forms of topical silicone exists other than silicone sheeting such as creams, spray, gel cushion and liquid. The forms of the topical silicone used in Barbados are silicone gel sheeting and silicone liquid (personal observations).

\section{Pressure therapy}

Pressure therapy has been used as a means of treating and managing keloids and hypertrophic scars for decades. Compression techniques are widely used in the treatment of burn and hypertrophic scarring. This is also the case in Barbados (personal observations). It is hypothesized that increased pressure to the scar surface limits perfusion, and reduced oxygen to the site of injury results in decreased collagen synthesis (39). It is also thought that pressure reduces scar hydration stabilizing mast cells and reducing angiogenesis (40). There is, however, still much uncertainty regarding the underlying mechanism. The application of pressure can be achieved via a number of methods ranging from bandages to buttons. The recent developments in magnet-applied pressure therapy have proven successful, with the overall recurrence-free rates of $89.4 \%$ (41). A continuous pressure of $20-25 \mathrm{mmHg}$ for 12-23 hours per day for more than six months is recommended (42). One central constraint of this treatment pertains to the scars anatomical location. Not every scar may present in an appropriate site, either due to psychological distress or difficulties associated with attaching a pressure garment. Due to the latter issue, the pressure garment is predominantly used for auricular keloids (43, 44). A significant beneficial outcome of pressure therapy is that it bypasses the issue of pain that tends to accompany intralesional therapies.

\section{Radiation therapy}

The use of radiation therapy for the treatment of keloids was first introduced in the early 1900's. Since then, it has been used as a monotherapy to a lesser extent (22) and more commonly, as an effective adjunct therapy following surgical excision (45) with success rates of $67 \%$ to $98 \%$ (46). When used as a combined therapy with surgery, the recurrence rates of keloids have been shown to decrease $(45,47)$. Radiation therapy has been shown to effectively reduce pain, pruritus and tenderness that are often associated with keloids (48). Different types of radiation have been used as adjunct therapy postsurgical excision and include: superficial X-rays, brachytherapy and electron beam with varying degrees of success (45). Radiation has been shown to work by reducing fibroblast proliferation by inducing apoptosis and restoring the balance between the production and degradation of scar collagen $(49,50)$. The recommended dose for radiation for the treatment of keloids varies from three to 40 Gy (46) depending on the anatomical site (28). Some of the side-effects of radiation include: hyperpigmentation, scarring radiation dermatitis, atrophy and the increased risk of cancer. Due to the latter, the use of radiation therapy has been restricted to adults only as well as the low carcinogenic areas that do not include the thyroid and breast.

In Barbados, the use of radiotherapy as an adjunct therapy following surgical excision is commonly used as second line therapy approach. Typically, superficial X-ray of 12 Gy in three fractions on three consecutive days, ideally starting from the first operative day, 
is performed (RK Shenoy, personal communication). A prospective clinical study of 46 ear keloids in 31 patients was conducted in 2006 at the Queen Elizabeth hospital, Barbados, using three protocols for keloid treatment. Following keloid excision, a postoperative intralesional triamcinolone injection at monthly intervals was given, a postoperative superficial X-ray of $12 \mathrm{~Gy}$ in three fractions on three consecutive days, was performed or a combination of superficial X-ray therapy and intralesional triamcinolone were given. The results obtained from the study demonstrated that, surgical keloid excision followed by radiotherapy and / Intralesional triamcinolone as adjunct therapies, were reliable methods with few complications. Regular clinical follow-up was found to be an important factor for preventing keloid recurrence (18).

\section{Imiquimod}

Imiquimod $5 \%$ cream is a topical immune response modulator approved for the treatment of warts, actinic keratosis and basal cell carcinoma in adults. It is thought to work by inducing the pro-inflammatory cytokine interferon-alfa (interferon- $\alpha$ ) which enhances collagen degradation and by causing pro-apoptotic effects (51). Imiquimod has been successfully used postoperatively following keloid excision (52). Conversely, another study also reported the recurrence of presternal keloids following keloid excision and imiquimod treatment (53) indicating the need for more controlled studies to be conducted to gain a full insight into the efficacy of imiquimod treatment of keloids. In Barbados, imiquimod cream is typically used on small keloids with varying degrees of success (personal observations).

\section{Cryotherapy}

Cryotherapy applies low temperatures to the keloid. The effects of freezing causes vascular injury that ultimately results in tissue necrosis (54). This therapy has proven most successful when combined with other treatments, especially intralesional triamcinolone acetonide injections (55). It is common to administer cryotherapy before intralesional triamcinolone acetonide injection for the best outcomes (56). The positive effects of liquid nitrogen and cryotherapy have been reported in a number of studies, with success rates varying from 32 to $74 \%$ and better outcomes with hypertrophic scars compared with keloids $(57,58)$. The recommendations for treatment include: two freeze-thaw cycles of 15 to 30 seconds every three weeks for up to 10 visits (59).
Recently, an intralesional cryoneedle has been developed. Superior results have been reported using the cryoneedle over contact/spray probes (59). Studies have shown volume reductions up to $67 \%$ in a single session (59). The usefulness of cryotherapy is limited to newer scars, as older scars tend not to exhibit sufficient vasculature necessary for the treatment's mechanism of action (57). A number of adverse effects are associated with cryotherapy including: pain, atrophy and hypopigmentation, which is common amongst dark-skinned patients. A case study presented at the Caribbean Dermatology Association in Jamaica reported that the use of cryotherapy on a large pinna keloid on a patient led to its reduction but resulted in hypopigmentation (unpublished data). In Barbados, cryotherapy is used but is not a common mode of treatment (personal observations).

\section{Management of keloids}

Managing keloids is a challenging process for the healthcare physician. A number of factors have to be taken into consideration for their optimum management. Carrying out a comprehensive clinical assessment is essential before deciding on the best treatment option. Taking a full medical history to ascertain any previous keloids in the patients or in their family is also important (25). When performing surgical excision, it important to close the wound with very little or no tension (31). A full assessment of the keloid scar including: keloid size, body location, skin type, cause of keloid and treatment length, should also be performed before choosing the most suitable treatment or the combination of treatments for the individual patient. It is necessary to keep the patients' pain, pruritus and inflammation under control (25) as well as closely monitor the scar site to prevent a recurrence.

\section{CONCLUSION}

Keloids are problematic scars that are difficult to treat and remove. This present review has explored and discussed the current literature of the various modes of keloid therapies available in Barbados along with keloid management. Intralesional triamcinolone acetonide injection, imiquimod, surgical excision, pressure dressing, silicone gel sheeting and radiation are among the modalities commonly used. Cryotherapy, although used, is not a common mode of treatment. A combinational approach is considered the most effective. Despite there being a greater array of treatments that are not currently used in Barbados, those employed are among the most 
traditional and reliable treatment methods. It is possible in the foreseeable future that other forms of therapy will become available in Barbados. Of crucial importance, however, is the management of keloids. A well-planned treatment strategy that takes into account the patient's needs by a highly experienced healthcare physician is instrumental in the eradication of keloids. Factors like keloid size and location, skin type and the age of the patient, have to be taken into consideration before deciding on the best-line of treatment which should also be tailored to the specific needs of the patient. Patient pain, pruritus and inflammation management, close clinical monitoring, as well as patient compliance with posttreatment care are also equally important.

\section{AUTHORS' NOTE}

The authors have no conflicts of interest to disclose.

\section{AUTHORSHIP}

NO conceived the study. NO and OJN participated in its design, coordination and drafting of the manuscript. JW and ALF helped draft the manuscript. All the authors were involved in writing the paper and gave approval for the submitted version.

\section{REFERENCES}

1. Clark RA, Ghosh K, Tonnesen MG. Tissue engineering for cutaneous wounds. J Invest Dermatol 2007; 127: 1018-29.

2. Peacock EE, Jr., Madden JW, Trier WC. Biologic basis for the treatment of keloids and hypertrophic scars. South Med J 1970; 63: 755-60.

3. Goldenberg G, Luber AJ. Use of intralesional cryosurgery as an innovative therapy for keloid scars and a review of current treatments. J clin Aesthet Dermatol 2013; 6: 23-6.

4. Satish L, Babu M, Tran KT, Hebda PA, Wells A. Keloid fibroblast responsiveness to epidermal growth factor and activation of downstream intracellular signaling pathways. Wound Repair Regen 2004; 12: 183-92.

5. Louw L. Keloids in rural black South Africans. Part 1: general overview and essential fatty acid hypotheses for keloid formation and prevention. Prostaglandins Leukot Essent Fatty Acids 2000; 63: 237-45.

6. Shih B, Bayat A. Genetics of keloid scarring. Arch Dermatol Res 2010; 302: 319-39.

7. Viera $\mathrm{MH}$, Caperton $\mathrm{CV}$, Berman B. Advances in the treatment of keloids. J Drugs Dermatol 2011; 10: 468-80.

8. Halim AS, Emami A, Salahshourifar I, Kannan TP. Keloid scarring: understanding the genetic basis, advances, and prospects. Arch Plast Surg 2012; 39: 184-9.

9. Alhady SM, Sivanantharajah K. Keloids in various races. A review of 175 cases. Plast Reconstr Surg 1969; 44: 564-6.

10. Oluwasanmi JO. Keloids in the African. Clin Plast Surg 1974; 1: 179-95.

11. Atiyeh BS, Costagliola M, Hayek SN. Keloid or hypertrophic scar: the controversy: review of the literature. Ann Plast Surg 2005; 54: 676-80.

12. Bayat A, Arscott G, Ollier WE, Ferguson MW, Mc Grouther DA. Description of site-specific morphology of keloid phenotypes in an Afrocaribbean population. Br J Plastic Surg 2004; 57: 122-33.

13. Bayat A, Arscott G, Ollier WE, McGrouther DA, Ferguson MW. Keloid disease: clinical relevance of single versus multiple site scars. Br J Plast Surg 2005; 58: 28-37.
14. Brown JJ, Ollier W, Arscott G, Ke X, Lamb J, Day P et al. Genetic susceptibility to keloid scarring: SMAD gene SNP frequencies in AfroCaribbeans. Exp Dermatol 2008; 17: 610-3.

15. Brown JJ, Ollier WE, Arscott G, Bayat A. Association of HLA-DRB1* and keloid disease in an Afro-Caribbean population. Clin Exp Dermatol 2010; 35: 305-10.

16. Ashcroft KJ, Syed F, Arscott G, Bayat A. Assessment of the influence of HLA class I and class II loci on the prevalence of keloid disease in Jamaican Afro-Caribbeans. Tissue Antigens 2011; 78: 390-6.

17. Smith OJ, McGrouther DA. The natural history and spontaneous resolution of keloid scars. J Plast Reconstr Aesthet Surg 2014; 67: 87-92.

18. Narakula GK, Shenoy RK. A prospective clinical review of "multi model" approach for treating ear keloids. Indian J Plast Surg 2008; 41: $2-7$.

19. Trisliana Perdanasari A, Lazzeri D, Su W, Xi W, Zheng Z, Ke L et al. Recent developments in the use of intralesional injections keloid treatment. Arch Plast Surg 2014; 41: 620-9.

20. Love PB, Kundu RV. Keloids: an update on medical and surgical treatments. J Drugs Dermatol 2013; 12: 403-9.

21. Jalali M, Bayat A. Current use of steroids in management of abnormal raised skin scars. Surgeon 2007; 5: 175-80.

22. Darzi MA, Chowdri NA, Kaul SK, Khan M. Evaluation of various methods of treating keloids and hypertrophic scars: a 10-year follow-up study. Br J Plast Surg 1992; 45: 374-9.

23. Robles DT, Berg D. Abnormal wound healing: keloids. Clin Dermatol 2007; 25: 26-32.

24. Ud-Din S, Bayat A. New insights on keloids, hypertrophic scars, and striae. Dermatol Clin 2014; 32: 193-209.

25. Ud-Din S, Bowring A, Derbyshire B, Morris J, Bayat A. Identification of steroid sensitive responders versus non-responders in the treatment of keloid disease. Arch Dermatol Res 2013; 305: 423-32.

26. Roques $\mathrm{C}$, Teot $\mathrm{L}$. The use of corticosteroids to treat keloids: a review. Int J Low Extrem Wounds 2008; 7: 137-45.

27. Darougheh A, Asilian A, Shariati F. Intralesional triamcinolone alone or in combination with 5-fluorouracil for the treatment of keloid and hypertrophic scars. Clin Exp Dermatol 2009; 34: 219-23.

28. Sidle DM, Kim H. Keloids: prevention and management. Facial Plast Surg Clin North Am 2011; 19: 505-15.

29. O'Brien L, Pandit A. Silicon gel sheeting for preventing and treating hypertrophic and keloid scars. The Cochrane Database Syst Rev 2006; CD003826.

30. Reish RG, Eriksson E. Scar treatments: preclinical and clinical studies. J Am Coll Surg 2008; 206: 719-30.

31. Son D, Harijan A. Overview of surgical scar prevention and management. J Korean Med Sci 2014; 29: 751-7.

32. Mustoe TA, Cooter RD, Gold MH, Hobbs FD, Ramelet AA, Shakespeare PG et al. International clinical recommendations on scar management. Plast Reconstr Surg 2002; 110: 560-71.

33. Puri N, Talwar A. The efficacy of silicone gel for the treatment of hypertrophic scars and keloids. J Cutan Aesthet Surg 2009; 2: 104-6.

34. Quinn KJ, Evans JH, Courtney JM, Gaylor JD, Reid WH. Non-pressure treatment of hypertrophic scars. Burns Incl Therm Inj 1985; 12: 102-8.

35. Berman B, Viera MH, Amini S. Keloid and hypertrophic scar. Medscape [Internet]. [Updated 2014 March 19; cited 2015 May 13]. Available from: http://emedicine.medscape.com/article/1057599-overview.

36. Gold MH, Foster TD, Adair MA, Burlison K, Lewis T. Prevention of hypertrophic scars and keloids by the prophylactic use of topical silicone gel sheets following a surgical procedure in an office setting. Dermatol Surg 2001; 27: 641-4.

37. Bianchi FA, Roccia F, Fiorini P, Berrone S. Use of Patient and Observer Scar Assessment Scale for evaluation of facial scars treated with selfdrying silicone gel. J Craniofac Surg 2010; 21: 719-23.

38. Steinstraesser L, Flak E, Witte B, Ring A, Tilkorn D, Hauser J et al. Pressure garment therapy alone and in combination with silicone for the prevention of hypertrophic scarring: randomized controlled trial with intraindividual comparison. Plast Reconstr Surg 2011; 128: 306e-13e.

39. Macintyre L, Baird M. Pressure garments for use in the treatment of hypertrophic scars--a review of the problems associated with their use. Burns 2006; 32: 10-5. 
40. Kelly AP. Medical and surgical therapies for keloids. Dermatol Ther 2004; 17: 212-8.

41. Park TH, Seo SW, Kim JK, Chang CH. Outcomes of surgical excision with pressure therapy using magnets and identification of risk factors for recurrent keloids. Plast Reconstr Surg 2011; 128: 431-9.

42. Candy LH, Cecilia LT, Ping ZY. Effect of different pressure magnitudes on hypertrophic scar in a Chinese population. Burns 2010; 36: 1234-41.

43. Bran GM, Brom J, Hormann K, Stuck BA. Auricular keloids: combined therapy with a new pressure device. Arch Facial Plast Surg 2012; 14: 20-6.

44. Kadouch DJ, van der Veer WM, Mahdavian Delavary B, Kerkdijk D, Niessen FB. Therapeutic hotline: An alternative adjuvant treatment after ear keloid excision using a custom-made methyl methacrylate stent. Dermatol Ther 2010; 23: 686-92.

45. Guix B, Henriquez I, Andres A, Finestres F, Tello JI, Martinez A. Treatment of keloids by high-dose-rate brachytherapy: A seven-year study. Int J Radiat Oncol Biol Phys 2001; 50: 167-72.

46. Norris JE. Superficial X-ray therapy in keloid management: a retrospective study of 24 cases and literature review. Plast Reconstr Surg 1995; 95: $1051-5$.

47. Ragoowansi R, Cornes PG, Moss AL, Glees JP. Treatment of keloids by surgical excision and immediate postoperative single-fraction radiotherapy. Plast Reconstr Surg 2003; 111: 1853-9.

48. De Cicco L, Vischioni B, Vavassori A, Gherardi F, Jereczek-Fossa BA, Lazzari R, et al. Postoperative management of keloids: low-dose-rate and high-dose-rate brachytherapy. Brachytherapy 2014; 13: 508-13.

49. Lee KS, Jung JB, Ro YJ, Ryoo YW, Kim OB, Song JY. Effects of x-irradiation on survival and extracellular matrix gene expression of cultured keloid fibroblasts. J Dermatol Sci 1994; 8: 33-7.
50. Luo S, Benathan M, Raffoul W, Panizzon RG, Egloff DV. Abnormal balance between proliferation and apoptotic cell death in fibroblasts derived from keloid lesions. Plast Reconstr Surg 2001; 107: 87-96.

51. Zurada JM, Kriegel D, Davis IC. Topical treatments for hypertrophic scars. J Am Acad Dermatol 2006; 55: 1024-31.

52. Berman B, Kaufman J. Pilot study of the effect of postoperative imiquimod $5 \%$ cream on the recurrence rate of excised keloids. J Am Acad Dermatol 2002; 47: S209-11.

53. Malhotra AK, Gupta S, Khaitan BK, Sharma VK. Imiquimod $5 \%$ cream for the prevention of recurrence after excision of presternal keloids. Dermatology 2007; 215: 63-5.

54. Rusciani L, Paradisi A, Alfano C, Chiummariello S, Rusciani A. Cryotherapy in the treatment of keloids. J Drugs Dermatol 2006; 5: $591-5$.

55. Jaros E, Priborsky J, Klein L. Treatment of keloids and hypertrophic scars with cryotherapy. Acta Medica 1999; 42: 61-3.

56. Lahiri A, Tsiliboti D, Gaze NR. Experience with difficult keloids. Br J Plast Surg 2001; 54: 633-5.

57. Rusciani L, Rossi G, Bono R. Use of cryotherapy in the treatment of keloids. J Dermatol Surg Oncol 1993; 19: 529-34.

58. Zouboulis CC, Blume U, Buttner P, Orfanos CE. Outcomes of cryosurgery in keloids and hypertrophic scars. A prospective consecutive trial of case series. Arch Dermatol 1993; 129: 1146-51.

59. Har-Shai Y, Amar M, Sabo E. Intralesional cryotherapy for enhancing the involution of hypertrophic scars and keloids. Plast Reconstr Surg 2003; 111: 1841-52. 